\title{
Return Transmissions between ADRs and A-Shares of Dual-Listed Chinese Firms
}

\author{
Congsheng Wu \\ School of Business \\ University of Bridgeport
}

\author{
Ke Chen \\ Chongqing Jiaotong University \\ Sichuan, China
}

This paper has been accepted for publication and forthcoming in Managerial Finance. Ke Chen was a visiting scholar in the school of business from 2013 to 2014.

\section{Research Question}

Many Chinese firms are dual-listed in both China and U.S. (see PetroChina in the middle). The U.S. listing takes the form of American Depositary Receipts (ADRs) while the Shanghai listing takes the form of A-shares. Though ADRs and their underlying A-shares lack full fungibility due to regulatory constraints, they nevertheless represent the same claiming rights and hence should be affected by the same fundamentals. Several questions naturally arise:

\section{1) How do returns of ADRs and A-shares} affect each other?

2) Which market dominates in terms of price discovery?

3) How has the recent global financial crisis affected the return transmission dynamics?

This study attempts to shed some lights on these questions using a rigorous statistical method called bivariate vector auto-regression (VAR) model. We also account for the nonsynchronous trading problem caused by the fact that the two markets are located in different time zones and that the two market observe different national and religious holidays.

\section{Data and Sample}

Our sample consists of ten Chinese firms that are dual-listed in New York and Shanghai. For each firm, we collect daily return data from the time it became dual listed up to year-end 2012. We define daily return as the log-difference in the closing prices at day $t$ and day $t-1$ in the stock market.

We analyze the whole sample period as well as two subperiods: before and after the global financial crisis. The line of demarcation is September 15, 2008, when Lehman Brothers declared bankruptcy, marking the start of the global financial crisis

\section{Contributions to Literature}

This paper distinguishes from previous studies and thus makes contributions to the literature in several ways.

First, we take into consideration the nonsynchronous trading issue.

Second, we consider whether and how the returns of ADRs and A-shares are affected by the market sentiments.

Third, we examine how the recent global financial crisis has altered the ADR and Ashare return feedback dynamics.

\section{The Relation between the Returns of ADRs and A-shares}

The trading hours of ADRs do not overlap with those of the Shanghai A-shares. Trading information at day $t$ in the Shanghai market may transmit to the U.S. market at same calendar day. The information at day $t$ in U.S. market, however, should transmit to the Shanghai market at day $\mathrm{t}+1$.

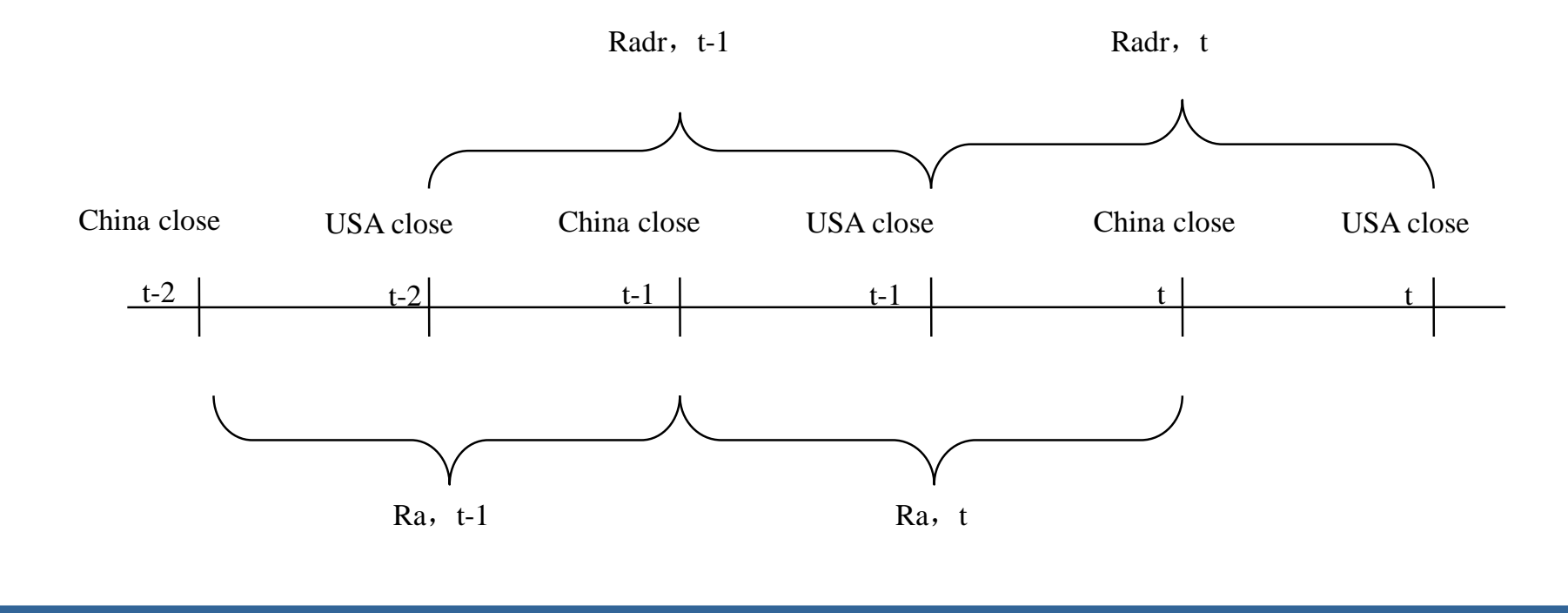

\section{Dual-Listed Chinese companies with ADRs and A-shares: An Example}

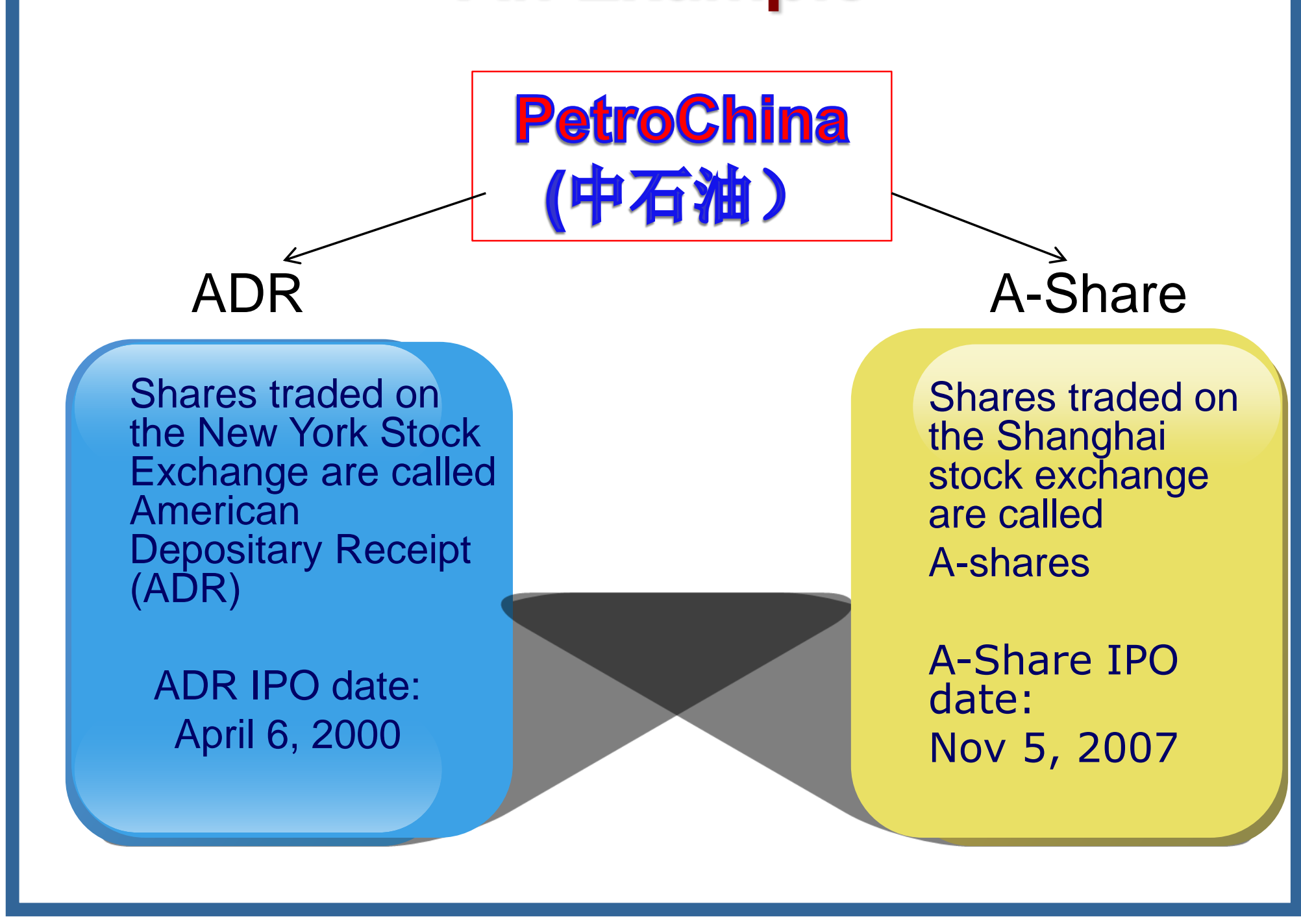

\section{Methodology}

In designing the test, we have to account for the non-synchronous trading issue because the two markets have differing national and religious holidays, unexpected events, and so forth. Another type of non-synchronous trading occurs because ADRs and A-shares are traded in separate markets with different time zones.

With this in mind, we use the following vector autoregression (VAR) model to assess the mutual information transmissions between the two return time series for each firm:

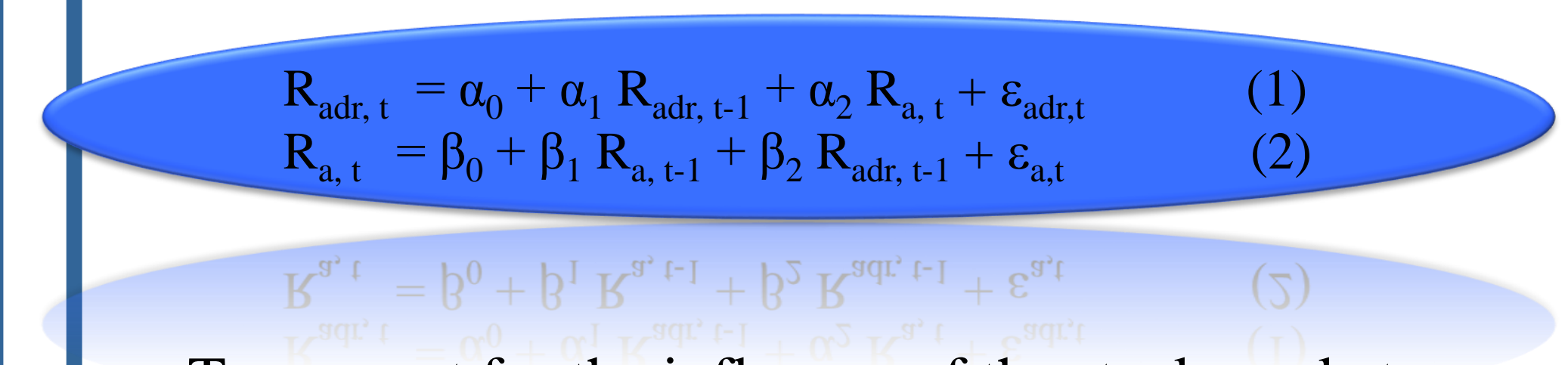

To account for the influence of the stock market sentiments, we add the market returns to the adjusted VAR model. The proxy for the U.S. market is the S\&P 500 index, and that for China is the Shanghai composite index. As a result, we have the following two equations where the market sentiments are introduced as exogenous variables to examine their mutual return effects for each firm:

\section{$\mathrm{R}_{\mathrm{adr}, \mathrm{t}}=\alpha_{0}+\alpha_{1} \mathrm{R}_{\mathrm{adr}, \mathrm{t}-1}+\alpha_{2} \mathrm{R}_{\mathrm{a}, \mathrm{t}}+\alpha_{3} \mathrm{R}_{\mathrm{us}, \mathrm{t}}+\varepsilon_{\text {adr, } \mathrm{t}}$ (3)}

Correlations Coefficients between ADRs and A-shares

\begin{tabular}{|c|c|c|c|c|c|c|}
\hline \multirow[b]{2}{*}{$\begin{array}{c}\text { Company } \\
\text { Symbol }\end{array}$} & \multicolumn{2}{|c|}{ Whole period } & \multicolumn{2}{|c|}{ Before the crisis } & \multicolumn{2}{|c|}{ After the crisis } \\
\hline & $\begin{array}{c}\text { Between } \\
\mathrm{R}_{\text {a.t. }} \text { and } \\
\mathrm{R}_{\text {adrt. }}\end{array}$ & $\begin{array}{c}\text { Between } \\
R_{\text {a, and }} \\
R_{\text {adrt.t-1 }}\end{array}$ & $\begin{array}{c}\text { Between } \\
R_{\text {at, }} \text { and } \\
R_{\text {adrt. }}\end{array}$ & $\begin{array}{c}\text { Between } \\
R_{\text {a, and }} \\
R_{\text {adrt.t. }}\end{array}$ & $\begin{array}{c}\text { Between } \\
R_{\text {a,ta }} \text { and } \\
R_{\text {adrt. }}\end{array}$ & $\begin{array}{c}\text { Between } \\
\mathbf{R}_{\text {a, and }} \\
\mathbf{R}_{\text {adr,tit }}\end{array}$ \\
\hline SHI & 0.150 & 0.045 & 0.107 & 0.031 & 0.362 & 0.117 \\
\hline HNP & 0.158 & 0.130 & 0.103 & 0.116 & 0.256 & 0.160 \\
\hline GSH & 0.219 & 0.056 & 0.202 & 0.039 & 0.241 & 0.073 \\
\hline CEA & 0.257 & 0.134 & 0.213 & 0.127 & 0.349 & 0.148 \\
\hline $\mathrm{ZNH}$ & 0.341 & 0.174 & 0.315 & 0.183 & 0.381 & 0.169 \\
\hline YZC & 0.210 & 0.095 & 0.129 & 0.049 & 0.358 & 0.179 \\
\hline PTR & 0.228 & 0.202 & 0.175 & 0.066 & 0.263 & 0.272 \\
\hline SNP & 0.270 & 0.154 & 0.257 & 0.152 & 0.302 & 0.163 \\
\hline ACH & 0.273 & 0.209 & 0.246 & 0.153 & 0.294 & 0.246 \\
\hline LFC & 0.338 & 0.146 & 0.267 & 0.166 & 0.400 & 0.135 \\
\hline Average & 0.244 & 0.135 & 0.201 & 0.108 & 0.321 & 0.166 \\
\hline
\end{tabular}

\section{Main Regression Results}

This table presents the results of Eqs. (3) and (4) using pooled data. Three sample periods, that is, the whole period, before and after the global financial crisis, are estimated separately. Returns on ADRs and A-shares at day $t$ are represented by $\mathrm{R}_{\mathrm{adr}, \mathrm{t}}$ and $\mathrm{R}_{\mathrm{a}, \mathrm{t}}$, respectively. The market return in U.S., $R_{u s, t}$, is represented by the S\&P 500 index, while the market return in China, $\mathrm{R}_{\mathrm{a}}$, is proxied by the Shanghai composite index. t-statistics are in the parentheses. $*$ indicates significance at $10 \%$ level, $* *$ indicates significance at $5 \%$ level, and $* * *$ indicates significance at $1 \%$ level.

\begin{tabular}{|c|c|c|c|c|c|c|}
\hline & \multicolumn{3}{|c|}{ Dependent variable: $\mathbf{R}_{\mathrm{adr}, \mathrm{t}}$} & \multicolumn{3}{|c|}{ Dependent variable: $\mathbf{R}_{\mathrm{a}, \mathrm{t}}$} \\
\hline & $\begin{array}{l}\text { Whole } \\
\text { sample }\end{array}$ & $\begin{array}{l}\text { Before } \\
\text { crisis }\end{array}$ & $\begin{array}{l}\text { After } \\
\text { crisis }\end{array}$ & $\begin{array}{l}\text { Whole } \\
\text { sample }\end{array}$ & $\begin{array}{c}\text { Before } \\
\text { crisis }\end{array}$ & $\begin{array}{l}\text { After } \\
\text { crisis }\end{array}$ \\
\hline Constant & $\begin{array}{c}0.0003 \\
(1.23)\end{array}$ & $\begin{array}{c}-0.0002 \\
(-0.27)\end{array}$ & $\begin{array}{l}0.0004 \\
(1.63)\end{array}$ & $\begin{array}{r}-0.0001 \\
(-0.70)\end{array}$ & $\begin{array}{l}0.0008 \\
(1.17)\end{array}$ & $\begin{array}{c}-0.0002 \\
(-0.89)\end{array}$ \\
\hline $\mathrm{R}_{\mathrm{adr}, \mathrm{t}-1}$ & $\begin{array}{c}-0.0841 \\
(-11.53)^{* * *}\end{array}$ & $\begin{array}{c}-0.0613 \\
(-3.05)^{* * *}\end{array}$ & $\begin{array}{c}-0.0885 \\
(-11.40)^{* * * * *}\end{array}$ & $\begin{array}{c}0.0396 \\
(6.91)^{* * * *}\end{array}$ & $\begin{array}{c}0.0584 \\
(3.33)^{* * *}\end{array}$ & $\begin{array}{c}0.0376 \\
(6.39)^{* * *}\end{array}$ \\
\hline $\mathrm{R}_{\mathrm{a}, \mathrm{t}}$ & $\begin{array}{c}0.3881 \\
(30.71)^{* * * *}\end{array}$ & $\begin{array}{c}0.3665 \\
(14.99)^{* * * * *}\end{array}$ & 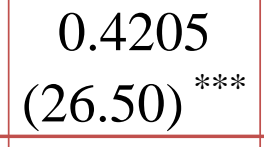 & & & \\
\hline $\mathrm{R}_{\mathrm{a}, \mathrm{t}-\mathrm{1}}$ & & & & $\begin{array}{c}0.0472 \\
(6.64)^{* * *} \\
\end{array}$ & $\begin{array}{c}0.073 \\
(4.49)^{* * * *}\end{array}$ & $\begin{array}{c}0.0349 \\
(4.27) \\
(4 * * * *\end{array}$ \\
\hline $\mathrm{R}_{\mathrm{us}, \mathrm{t}}$ & $\begin{array}{c}1.2863 \\
(86.07)^{* * *}\end{array}$ & $\begin{array}{c}1.6605 \\
(29.40)^{* * *}\end{array}$ & $\begin{array}{c}1.237 \\
(81.16)^{\text {****** }}\end{array}$ & & & \\
\hline $\mathrm{R}_{\mathrm{sh}, \mathrm{t}}$ & & & & $\begin{array}{c}1.0576 \\
(104.71)^{* * * * *}\end{array}$ & $\begin{array}{l}1.1297 \\
(47.91) \\
* * * *\end{array}$ & $\begin{array}{l}1.0179 \\
(87.76) \\
* * * *\end{array}$ \\
\hline $\begin{array}{c}\text { Sample } \\
\text { size }\end{array}$ & 10250 & 1570 & 8670 & 10250 & 1570 & 8670 \\
\hline Adj. $R^{2}$ & 0.48 & 0.39 & 0.5 & 0.53 & 0.6 & 0.48 \\
\hline
\end{tabular}

\section{Major Findings}

Using all dual-listed Chinese firms and daily return data up to year-end 2012, we find significant mutual return transmissions between ADRs and their underlying A-shares. In the absence of local market sentiments, the return transmission effect is more prevalent and stronger going from U.S. to China than it is the other way around.

However, after the market factors are included in our models, the mutual impacts and information flows between A-shares and ADRs become stronger and bidirectional. Additionally, both ADR and A-share returns are strongly affected by the market sentiment of the marketplace where they are traded. This finding in itself is interesting, for it suggests that Chinese ADRs are affected by the U.S. stock market where they are merely listed.

Finally, the recent global financial crisis has enhanced the linkage between ADRs and their corresponding A-shares. 